\title{
STABILITAS STATIS KAPAL IKAN TIPE LAMBUT TERSANJUNG YANG BERPANGKALAN DI PELABUHAN PERIKANAN SAMUDERA AERTEMBAGA KOTA BITUNG PROPINSI SULAWESI UTARA
}

\author{
Fransisco P.T. Pangalila \\ Staf Pengajar pada Program Studi Pemanfaatan Sumberdaya Perikanan, \\ Fakultas Perikanan dan IImu Kelautan UNSRAT, Manado, 95115.
}

\begin{abstract}
Ship is water vehicle with any shape and any purpose, mechanically powered or by windvor tug and categorized as a multipurpose platform. It could be operated underwater or in the surface of water and could function merely as a floating static structure. The natural condition is the fish catching area are unpredictable as the wave an current of the water could disturbing the maneuverability and the stabilty of the ship. For that purpose the fish catching ship should have and meet the criterion of robust construction and strong structure to deal with the extreme condition in the sea and also should have a good maneuverability and enough power to make it move steadily. The total lenght of the sample ship Tersanjung are $15.85 \mathrm{~m}$, the width are $2.90 \mathrm{~m}$ and inside the ship measured as $1.32 \mathrm{~m}$. The average comparison among the 3 parameters are 5.50 for $L / B, 13.05$ for $L / D$ and 2.37 for $\mathrm{B} / \mathrm{D}$. The coefficient of the Tersanjung ship are $\mathrm{Cb}=0.58, \mathrm{Cp}=0.96, \mathrm{C} \otimes=0.60$ and $\mathrm{Cw}=0.87$. "Tersanjung" ship has reverse velocity 3.7 second ( 1 perod). Maximum rolling reaching at 120 with righting moment of $0.21 \mathrm{~m}$.
\end{abstract}

\section{Key words: fishing boat, floating static, rolling.}

\section{PENDAHULUAN}

Kapal adalah kendaraan air dengan bentuk dan jenis apapun, yang digerakkan dengan tenaga mekanik, tenaga angin atau ditunda, termasuk kendaraan yang berdaya dukung dinamis, kendaraan di bawah permukaan air, serta alat apung dan bangunan terapung yang tidak berpindah-pindah (Undang-undang Republik Indonesia No. 21 Tahun 1992 tentang Pelayaran).

Ayodhyoa (1972) menyatakan bahwa apabila kita akan membuat kapal guna keperluan pengembangan usaha penangkapan ikan tentu saja terlebih dahulu harus memperhatikan berbagai persyaratan seperti pemilihan jenis kapal sesuai dengan jenis usaha (hand line, trawl, purse seine, pole and line, dan lain-lain), besarnya, bentuk, ukuran utama, kecepatan dan lainlain. Selanjutnya bentuk kapal ada yang langsing, montok dan gemuk. Koefisien yang menggambarkan keadaan ini, Coefisien block $(\mathrm{Cb})$ Coefisien waterline $(\mathrm{Cw})$, Coefisien perismatik (Cp) dan Coefisien midship $(\mathrm{C} \otimes)$.
Kondisi alam suatu daerah penangkapan tidaklah menentu, seperti terjadinya gelombang maupun arus yang datang sehingga mempengaruhi olah gerak dan stabilitas kapal. Untuk itu kapal perikanan harus memiliki dan memenuhi persyaratan khusus seperti konstruksi bangunan kapal yang kokoh dan tahan terhadap kondisi laut yang paling buruk sekalipun, namun tetap memiliki kemampuan olah gerak (manuver) yang baik serta daya dorong yang besar.

Masyarakat nelayan di Sulawesi Utara umumnya menggunakan kapal tipe lambut untuk melakukan penangkapan ikan cakalang (Katsuwonus pelamis). Kapal-kapal tersebut umumnya dibuat oleh pengrajin tradisional berdasarkan keahlian alami atau pengalaman turun-temurun, tanpa perencanaan gambar dan kurang aplikasi teknis yang sesuai dengan teori perkapalan.

Kurangnya pengontrolan bagi nelayan dan pembuat kapal mengenai stabil tidaknya kapal adalah salah satu penyebab sehingga operasi penangkapan tidak dapat berjalan dengan baik. 
Disamping itu dalam pembuatan kapal para pengrajin tidak memperhatikan hubungan antara besar kapal, tenaga pendorong dan kecepatan kapal, sehingga sering terjadi benturan antara keinginan untuk membuat kapal menjadi cepat tetapi kapal tersebut oleng dan tidak stabil, oleh sebab itu perlu dilakukan penelitian mengenai ukuran-ukuran utama, mengkaji stabilitas statis dan sudut Capzising pada kapal tipe lambut yang berpangkalan di Pelabuhan Perikanan Samudera Kota Bitung.

\section{TINJAUAN PUSTAKA}

Inclining Experiment atau yang disebut juga pengujian kemiringan adalah praktek investigasi stabilitas dalam menyelesaikan pembuatan kapal untuk semua kapal baru, Hind (1967). Objek dari pengujian ini dikenal sebagai posisi center of gravity dan menjadi alasan untuk sebuah praktek investigasi karena posisi $G$ tidak dapat dihitung dengan beberapa derajat dari kemampuan gambar desain. Tujuan utama pengujian kemiringan adalah nilai tertinggi dari titik metacentris. Juga dijelaskan bahwa posisi center of gravity untuk nilai yang akurat dibutuhkan untuk membuat kapal tetap dalam keadaan stabil pada saat pengoperasian. Oleh karena itu inclining experiment ditampilkan untuk memperoleh jarak vertikal dari titik $\mathrm{G}$ di atas titik $\mathrm{K}$ secara akurat ketika kapal dalam keadaan tenang/stabil.

Hind (1967) menyatakan, keselamatan pelayaran suatu kapal lebih banyak ditentukan oleh stabilitas. Stabilitas kapal adalah kemampuan kapal tersebut untuk kembali ke posisi semula setelah mengalami gaya-gaya tarik dari luar maupun dari dalam kapal yang menyebabkan kapal itu miring. Selanjutnya dijelaskan bahwa pada suatu benda yang mengapung diam di permukaan air terdapat dua gaya utama yang sama besar dan bekerja berlawanan arah pada sumbu vertikal, yaitu gaya berat $G$ (Center of Gravity) dan gaya apung $B$ (Center of Buoyancy).

Lester (1985) menyatakan bahwa terdapat 3 titik yang memegang peranan penting dalam peninjauan stabilitas suatu kapal yaitu titik G, B dan M. Selanjutnya menurut Kok (1983), titik berat G (Center of gravity) adalah titik resultan gaya berat seluruh bagian kapal termasuk semua isi yang berada didalamnya yang menekan ke bawah; titik apung B (Bouyancy) adalah titik berat geometris bagian kapal yang terbenam dalam air yang menekan ke atas dan titik $M$ (Metacenter) adalah tinggi sudut inklinasi dari lunas kapal serta titik pusat garis yang bekerja gaya apung dan gaya berat. Gaya-gaya yang menyebabkan terjadinya stabilitas adalah gaya berat $G$ yang besarnya sama dengan pemindahan air D (displacement), dan gaya apung yang bekerja pada $B$ yang sama juga besarnya dengan pemindahan air $\mathrm{D}$ (displacement) seperti dikemukakan dalam hukum Archimedes: "Sebuah benda yang seluruhnya atau sebagian tercelup di dalam suatu fluida akan diapungkan ke atas dengan sebuah gaya yang sama dengan berat fluida yang dipindahkan oleh benda tersebut". Bila G dan B letaknya tidak vertikal segaris, maka akan terjadi momen kapal bergerak sesuai arah momen.

Berdasarkan posisi relatif titik $M$ terhadap G, maka Muckle (1978) menyatakan sebagai berikut :

1. Apabila titik $G$ berada di bawah titik $M$ maka momen penegak (Righting moment, $\mathrm{RM}=\Delta . \mathrm{GZ}$, sedangkan $\mathrm{GZ}=\mathrm{GM}$ $\operatorname{Sin} \theta$ ) bernilai positif karena lengan penegak (GZ) bernilai positif. Momen penegak ini sanggup mengembalikan kapal ke posisi tegak semula. Stabilitas yang demikian disebut stabilitas positif (stabil).

2. Apabila titik $G$ dan $M$ berimpit, maka momen penegak (RM) akan sama dengan nol karena tidak terbentuk lengan penegak $(G Z=0)$ sehingga $\mathrm{RM}=0$. Ini berarti apabila kapal sengat (olengan cepat) maka kapal tersebut akan tetap sengat sebab tidak ada lengan penegak. Stabilitas yang demikian disebut stabilitas netral.

3. Apabila titik $G$ berada di atas titik $M$ maka momen penegak (Righting moment, RM) bernilai negatif karena lengan GZ bernilai negatif. Momen penegak ini tidak mampu mengembalikan kapal ke posisi tegak semula, malah membantu memiringkan kapal dan kemungkinan kapal terbalik. Stabilitas 
yang demikian disebut stabilitas negatif (labil).

Stabilitas adalah kemampuan kapal untuk kembali ke posisi semula sesudah miring akibat bekerjanya gaya-gaya terhadap kapal (Hind, 1967). Sebaliknya Edward dan Robert (1980), menyatakan bahwa stabilitas adalah kombinasi antara ukuran yang cocok dan pembagian berat muatan yang memungkinkan kapal untuk mengikuti kekuatan angin dan gelombang, serta selalu dapat kembali tegak dan seimbang lagi atau kecenderungan kapal yang bergoyang ke kiri dan kekanan untuk kembali ke posisi tegak. Selanjutnya Handryanto (1982) menambahkan bahwa stabilitas adalah kehendak dari kapal untuk kembali kekeadaan semula apabila kapal tersebut mendapat tenaga atau gaya dari luar.

Stabilitas statis adalah kecenderungan kembalinya kapal ke posisi semula setelah kapal cenderung dimiringkan pada saat kapal dalam keadaan diam. Ini adalah bukti bahwa dibawah kondisi biasa kapal tidak selalu dalam keadaan lurus. Kapal secara terus menerus dipaksa keluar dari posisi lurusnya oleh gaya-gaya dari luar seperti angin dan gelombang. Sangatlah penting bahwa kapal harus memiliki kualitas tertentu sehingga sudut miring yang terjadi tidak mempangaruhi keamanannya.

Kapal dikatakan stabil jika pada saat kapal dimiringkan, kapal cenderung kembali ke posisi semula dengan periode olengan relatif pendek. Kapal dikatakan tidak stabil jika pada saat dimiringkan lambat kembali ke posisi semula, periode olengan kapal relatif panjang untuk kembali pada keadaan semula. Kapal dikatakan dalam keadaan netral jika, pada saat kapal dimiringan tidak menjauh dari posisi semula (Attwood dan Pengelly, 1967).

\section{METODE PENELITIAN}

Penelitian ini dilakukan di kota Bitung Propinsi Sulawesi Utara, tepatnya di lokasi Pelabuhan Perikanan Samudera Aertembaga, Bitung. Selanjutnya data yang diperoleh diolah di Laboratorium Kepelautan Fakultas Perikanan dan IImu Kelautan Universitas Sam Ratulangi
Manado. Waktu penelitian dilaksanakan dari bulan Oktober sampai November tahun 2010.

Objek penelitian ini adalah kapal tipe lambut jenis small pole and liner, dengan mengambil data kapal bernama Tersanjung sebagai contoh, yang diukur dan digambar kembali desainnya.

\section{Teknik Pengumpulan Data}

Teknik pengumpulan data dilakukan melalui pengamatan dan pengukuran secara langsung di lapangan, serta wawancara untuk memperoleh data primer dan pengutipan informasi dari beberapa tulisan ilmiah sesuai dengan topik penelitian untuk memperoleh data sekunder.

1. Pengukuran Ukuran Utama Kapal

a. LOA (Length Over All), panjang seluruh kapal yang diukur dari bagian paling ujung buritan hingga bagian paling ujung pada haluan.

b. BM (Breadth Moulded), lebar kapal yang diukur mulai dari sisi luar kapal yang satu kesisi lainnya.

c. D (Depth), dalam atau tinggi kapal yang diukur mulai dari dek terendah hingga ke bagian badan kapal terbawah.

d. LWL (Length Water Line), panjang garis air.

e. d (draf), dalam sarat kapal yang diukur dari Lwl (garis air kondisi kapal kosong) hingga kebawah kapal terbawah atau lunas bagian atas.

2. Penggambaran Lambung Kapal

Untuk menggambarkan lambung kapal digunakan teknik pengukuran dengan pantograf bagi kapal yang berada di atas air, prosedurnya sebagai berikut:

a. Pada saat pengukuran kapal dalam kondisi lurus jika di darat dan diam atau dalam keadaan terikat pada kapal lain jika di air.

b. Bentangkan tali dari buritan kapal ke haluan kapal.

c. Lakukan pengukuran panjang kapal secara keseluruhan (LOA).

d. Panjang keseluruhan kapal dibagi menjadi 10 section dari buritan ke haluan, dan tandai pada tali.

e. Setelah semua siap gambarlah garis lambung kapal pada setiap section pada lambung kapal dengan meng- 
gunakan pantograph dengan cara ujung lengan pantograph dijepitkan pada freeboard deck line kemudian tarik ujung lengan pantograph mengikuti bentuk kapal sampai pada freeboard deck line.

f. Pada saat pengukuran lebar dan dalam kapal setiap section diukur.

\section{Penentuan Olengan Bebas Kapal}

Aturan-aturan untuk mengukur GM dapat dilakukan dengan menggunakan percobaan momen sistem pengujian kemiringan (inclining experiment) yaitu:

a. Kapal diusahakan dalam keadaan diam atau dapat juga dengan cara mengikat kapal agar tidak oleng karena pengaruh ombak.

b. Menyiapkan beban yang telah diketahui beratnya.

c. Mengukur panjang lengan (Righting Arm) kapal pada bagian tengah kapal paling lebar.

d. Menempatkan klinometer pada bagian tengah kapal yang paling lebar.

e. Meletakkan beban pada bagian pinggir kapal yang paling lebar, kemudian sudut yang dibentuk pada klinometer dicatat.

f. Ketika semua alat sudah diset, kemudian berat 6 orang yang akan melakukan gerakan untuk mengolengkan kapal ditimbang.

g. Melakukan penambahan beban sebanyak tiga kali dimana dari setiap beban dilakukan tiga kali pengulangan.

h. 6 orang tersebut berdiri di tepi kapal untuk membentuk sudut, lalu berlari dari tepi lebar kapal yang satu ke tepi lebar kapal yang lainnya, pengulangan dilakukan selama 3 kali, lalu ke-enam orang diam di bagian tengah kapal.

i. Setelah kapal melakukan gerak oleng angka-angka yang ditunjukan oleh bandul ketika benang bandul bergerak di samping busur dibaca skalanya.

\section{E. Analisis Data}

1. Menghitung Volume kapal

Volume kapal dihitung dengan menggunakan aturan trapesium, seperti yang dikemukakan oleh Namura dan Yamazaki (1977) dengan rumus:

$$
\begin{aligned}
& A=\frac{H}{2}\left(y_{1}+2 y_{2}+2 y_{3}+\ldots+2 y_{m-1}+y_{m}\right) \\
& \nabla=\frac{H}{2}\left(A_{1}+2 A_{2}+2 A_{3}+\ldots .+2 A_{m-1}+A_{m}\right)
\end{aligned}
$$

dimana:

$$
\begin{aligned}
& \nabla=\text { Volume Kapal }\left(\mathrm{m}^{3}\right) \\
& A=\text { Luas bidang }\left(\mathrm{m}^{2}\right) \\
& \mathrm{H}=\text { Jarak antara bidang/garis }(\mathrm{m}) \\
& A_{i}=\text { Luas bidang ke-i }\left(\mathrm{m}^{2}\right) \\
& y_{i}=\text { panjang garis ke-i }(\mathrm{m}) \\
& i=1,2,3, \ldots \ldots . \mathrm{m} \text { (jumlah Bidang) }
\end{aligned}
$$

\section{Koefisien Bentuk Kapal}

Untuk menghitung nilai dari masing-masing koefisien bentuk, maka digunakan rumus yang dikemukakan oleh Nomura dan Yamazaki (1977) sebagai berikut:

Koefisien Balok $\left(\mathrm{C}_{\mathrm{b}}\right)=\frac{\nabla}{\mathrm{LWL} \times \mathrm{BWL} \times \mathrm{d}}$

Koefisien Prismatik $\left(C_{p}\right)=\frac{\nabla}{A_{\otimes} \times L W L}=\frac{C_{b}}{C_{\otimes}}$

Koefisien bidang tengah $\operatorname{kapal}\left(\mathrm{C}_{\otimes}\right)=\frac{\mathrm{A}_{\otimes}}{B W L \times d}$

Koefisien bidang garis air $\left(C_{w}\right)=\frac{A_{w}}{L W L \times B W L}$

dimana:

$\mathrm{LWL}=$ Panjang Kapal pada water line $(\mathrm{m})$

$B W L=$ Lebar kapal pada water line $(m)$

$\mathrm{d}=\operatorname{draft}(\mathrm{m})$

$A_{w}=$ Luas bidang garis tengah air $\left(\mathrm{m}^{2}\right)$

$A_{\otimes}=$ Luas bidang penampang tengah $\left(\mathrm{m}^{2}\right)$

$\nabla=$ Volume $\left(\mathrm{m}^{3}\right)$

3. Pengukuran dan Perhitungan stabilitas kapal

Pengukuran dilakukan dengan metode moment yaitu menggunakan beban yang diletakkan pada salah satu sisi kapal yang kemudian dilakukan pembacaaan terhadap setiap perubahan yang terjadi.

Untuk mengetahui olengan bebas digunakan koefisien froude (Dalzell, 1978), yang dapat menghitung Rolling dumping yaitu kurva yang menggambarkan besar olengan yang terjadi pada kapal.

$$
\Delta \phi=\mathrm{a} \phi_{\mathrm{n}}^{\prime}+\mathrm{b} \phi_{\mathrm{n}}^{\prime 2}
$$

dimana:

$$
\begin{array}{ll}
\Delta^{\phi} & =\text { Rolling dumping } \\
\mathrm{a}, \mathrm{b} & =\text { Koefisien Extinsi }
\end{array}
$$


Untuk menentukan curve extinction (Koefisien $\mathrm{N}$ ) digunakan:

$$
\Delta \phi^{\prime}=\frac{\Delta \phi}{\left(\phi_{i}+\phi_{i+1)} / 2\right.}
$$

Hasil perhitungan selanjutnya dipetakan dalam kurva stabilitas statis dengan menggunakan rumus:

$$
\int_{0}^{\phi} \mathrm{m} \phi \mathrm{d} \phi=\int_{0}^{\phi} \mathrm{w} \cdot \overline{\mathrm{GZ}} \mathrm{d} \phi=\int_{0}^{\phi} \Delta \cdot \overline{\mathrm{GZ}} \mathrm{d} \phi
$$

dimana:

$$
\begin{aligned}
\mathrm{m}^{\phi} & =\text { Momen penegak } \\
{ }_{\mathrm{d}} \phi & =\text { Sudut tambahan } \\
\overline{\mathrm{GZ}} & =\text { Lengan penegak }
\end{aligned}
$$

\section{HASIL DAN PEMBAHASAN}

\section{Ukuran Utama Kapal}

Dari hasil pengukuran pada kapal Tersanjung menunjukkan bahwa panjang total kapal adalah $15,85 \mathrm{~m}$, lebar kapal adalah 2,90 $\mathrm{m}$ dan untuk dalam kapal yaitu $1,32 \mathrm{~m}$. Selanjutnya data ukuran utama kapal disajikan pada tabel 1.

Dari nilai-nilai perbandingan yang diperoleh, dapat dikatakan bahwa kapalkapal tipe lambut yang berpangkalan di Pelabuhan Perikanan Samudera Aertembaga kota Bitung memiliki perbandingan yang sesuai untuk panjang dan lebar, hal ini memberikan pengaruh yang baik terhadap tahanan kapal. Tahanan yang terjadi pada saat kapal berlayar berkurang sehingga dapat meningkatkan kecepatan kapal.

Perbandingan panjang dan dalam kapal, memiliki nilai yang besar ini memberi pengaruh terhadap kekuatan memanjang kapal, sehingga kapal tidak mudah patah pada saat mendapatkan gaya-gaya dari luar yang bekerja mempengaruhi kekuatan memanjang dari kapal tersebut.

Tabel 1. Ukuran Utama Kapal Tersanjung dan Perbandingan Ukuran Utama Kapal tipe lambut yang berpangkalan di Pelabuhan Perikanan Samudera Bitung.

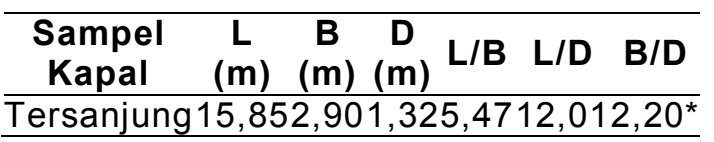

\section{Koefisien Bentuk Kapal}

Koefisien bentuk kapal merupakan ukuran yang dapat menggambarkan bentuk kapal menyangkut kemontokan dan kelangsingan bentuk lambung kapal tersebut pada benaman kolom air. Hasil penelitian yang dilakukan pada kapal Tersanjung, diperoleh hasil seperti yang ditampilkan pada tabel 2.

Tabel 2. Koefisien Bentuk Kapal Tersanjung tipe lambut yang berpangkalan di Pelabuhan Perikanan Samudera Bitung.

\begin{tabular}{ccccc}
\hline $\begin{array}{c}\text { Sampel } \\
\text { Kapal }\end{array}$ & $\mathbf{C}_{\mathrm{b}}$ & $\mathbf{C}_{\mathrm{p}}$ & $\mathbf{C}_{\otimes}$ & $\mathbf{C}_{\mathrm{w}}$ \\
\hline Tersanjung & 0,58 & 0,96 & 0,60 & $0,87^{*}$ \\
\hline
\end{tabular}

Nilai koefisien balok pada tabel 2 menunjukkan bahwa volume benaman kapal Tersanjung dalam bentuk balok 0,58, ini mengartikan bahwa benaman kapal adalah $58 \%$ dari volume kapal dalam bentuk balok. Hal ini juga menjelaskan bahwa kapal Tersanjung tersebut bentuk lambungnya langsing sehingga menguntungkan dalam kecepatan kapal.

Nilai koefisien perismatik kapal Tersanjung dari hasil perhitungan diperoleh bahwa luas bidang penampang melintang tengah kapal 0,96. Nilai ini menunjukkan bahwa perbandingan antara volume kapal dibagi dengan perkalian antara bagian tengah kapal secara memanjang adalah sebesar $96 \%$, artinya bahwa kapal Tersanjung tipe lambut melebar pada bagian buritan.

Nilai penampang tengah kapal Tersanjung yaitu 0,60 . Hal ini menunjukkan bahwa luas bidang penampang melintang tengah kapal Tersanjung adalah $74 \%$, ini mengartikan bahwa kapal tipe lambut Tersanjung memiliki bentuk lambung yang relatif mendekati huruf $\mathrm{V}$. Hal ini dapat mempengaruhi kecepatan kapal, dimana tahanannya relatif rendah sehingga meningkatkan kecepatan.

Nilai koefisien bidang air yaitu 0,87 . Hal ini menunjukkan bahwa kapal tipe lambut Tersanjung memiliki bentuk penampang garis air yang mendekati bentuk empat persegi, sehingga meningkatkan stabilitas kapal. 
Dari hasil penelitian dan dibandingkan dengan penelitian sebelumnya terlihat bahwa para pengrajin kapal telah memperhitungkan kecepatan kapal dimana bentuk lambung kapal adalah langsing serta bentuk penampang melintang kapal mendekati huruf $V$ dimana sangat menguntungkan pada kecepatan kapal.

Jika dilihat dari koefisien prismatik dan koefisien bidang air terlihat bahwa para pengrajin sangat mengutamakan kestabilan kapal, ini dibuktikan dengan nilai koefisien prismatik dan koefisien bidang air yang besar yang menyebabkan bentuk kapal melebar pada bagian buritan kapal dan koefisien bidang air yang hampir berbentuk empat persigi dimana sangat menguntungkan pada kestabilan kapal.

\section{Olengan Bebas}

Implementasi teori olengan bebas dalam hal ini stabilitas statis yang dilakukan saat kapal diam telah dilakukan pada kapal tipe lambut Tersanjung dengan hasil seperti yang tertera pada gambar 1 .

Gambar 1 menerangkan bahwa sumbu $X$ adalah waktu dalam detik yang diperlukan oleh kapal untuk kembali dalam posisi netral, sedangkan sumbu $Y$ adalah kemiringan sudut yang terbentuk ketika kapal oleng selama waktu $t$. Gambar 1 menunjukkan bahwa Tersanjung memiliki kecepatan pembalikan 3,7 detik (1 kali periode oleng). Jika dibandingkan dengan periode oleng kapal yang sama di daerah yang sama pula, ternyata Tersanjung memiliki periode oleng yang relatif pendek, yang akhirnya berkontribusi pada tingkat stabilitas kapal tersebut.

Hasil analisis lanjutan untuk menentukan stabilitas statis dari Tersanjung dijelaskan pada gambar 2. Hasil yang ditampilkan pada gambar 2 yaitu pengukuran pada saat kapal dalam kondisi kosong $\nabla=5,7$ ton, pada draft $0,77 \mathrm{~m}$ dengan nilai $\mathrm{GM}=1,027 \mathrm{~m}$. Gambar 19 menjelaskan bahwa olengan maximum kapal dalam kondisi tersebut mencapai kemiringan $12^{\circ}$ dengan nilai lengan penegak sebesar $0,21 \mathrm{~m}$, ini berarti bahwa stabilitas kapal ini baik.

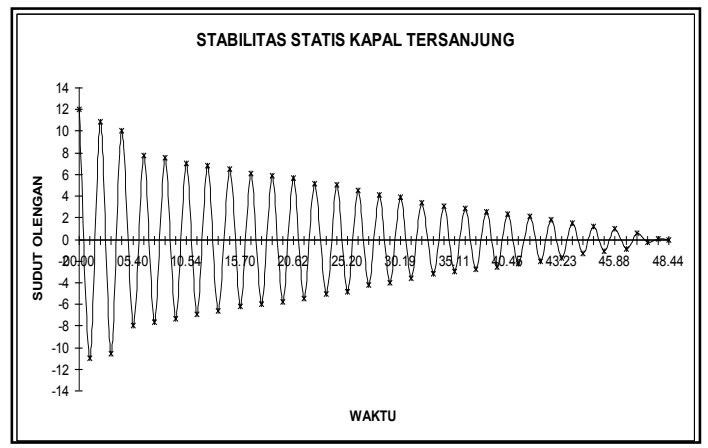

Gambar 1. Olengan bebas Kapal Tersanjung

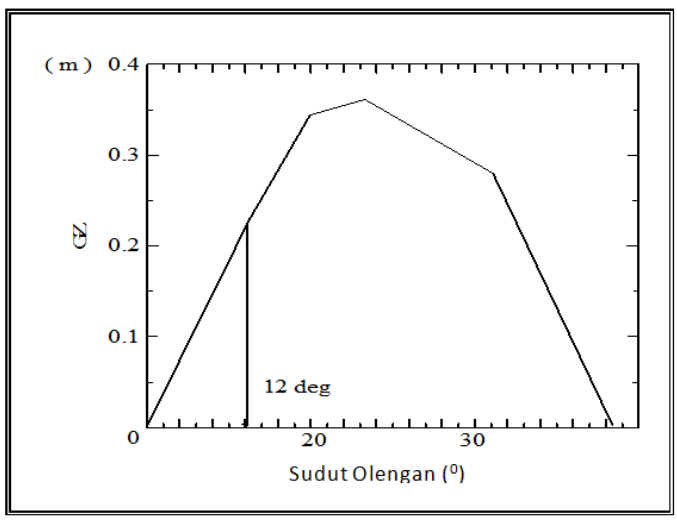

Gambar 2. Kurva Stabilitas Statis Kapal tipe lambut Tersanjung

\section{KESIMPULAN DAN SARAN}

\section{Kesimpulan}

Dari hasil penelitian tentang stabilitas statis kapal tipe lambut yang berpangkalan di Kota Bitung ditarik kesimpulan sebagai berikut:

1. Kapal tipe lambut yang berpangkalan di TPI Aertembaga kota Bitung mempunyai nilai perbandingan ukuran utama kapal yang relatif baik. Nilai koefisien bentuk kapal Tersanjung ini cenderung mewakili nilai koefisien kapal sejenis di daerah lain.

2. Kapal Tersanjung memiliki bentuk yang cenderung bulat. Ini memberi kontribusi yang positif terhadap stabilitas statis kapal.

3. Kapal Tersanjung sudut capzising yang diperoleh adalah $12^{\circ}$, hal ini menunjukkan bahwa kapal ini tersebut memiliki sudut oleng yang kecil.

\section{Saran}

Dari hasil penelitian dan pembahasan yang telah dilakukan, telah diambil kesimpulan, maka penulis ingin mengemukakan beberapa saran yaitu: 
1. Perlunya sosialisasi teknik pengukuran stabilitas statis kepada pengusaha kapal, nelayan dan galangan kapal tradisional di Sulawesi Utara.

2. Perlu dilakukan penelitian dan pengkajian stabilitas dinamis dan manuver pada saat kapal sedang berlayar maupun sedang melakukan operasi penangkapan ikan.

\section{DAFTAR PUSTAKA}

Ayodhyoa, A.U. 1972. Fishing Boat. Corespondence Course Centre. IPB. Bogor. $66 \mathrm{P}$

Ariyanto. 1986. Prosedur Penelitian Suatu Pendekatan Praktis. Bina Aksara. $53 \mathrm{Hal}$.

Atwood, E.L. O.B.E dan Pengelly, H.S. C.B. 1967. Theoritical Naval Architecture. Longmans. Great Britain.

Dalzell, J.F., 1978. A Note On The Form of Ship Roll Dumping. Journal of Ship Research 22 No. 3 pp. 1978-1985.

Handryanto, 1982. Pembuatan Gill Net 14,5 GT di PT. M. Jusdi. Tegal. Jawa Tengah. Karya Ilmiah. Fakultas Perikanan. IPB. Bogor. $134 \mathrm{Hal}$.

Hind, J.A. 1967. Trim and Stability of Fishing Vessel. Fishing News (Ltd. London. 120 P.

Karman, A. 1996. Pengaruh ukuran luas sirip terhadap stabilitas model kapal tipe lambut. Skripsi Fakultas Perikanan dan IImu Kelautan. UNSRAT. Mdo. 28 Hal.
Kok, H.G.M. 1983. Bangunan Kapal. Martech. $149 \mathrm{Hal}$.

Lester, A.P. 1985. Merchant Ship stability. Butter worth and Co. London $502 \mathrm{P}$.

Mandagi, I.F., 2003. Studi Tentang Penurunan Sudut Oleng (Roll Dumping) Pada Kapal Pukat Cincin di Pesisir Bitung dan Bunaken Propinsi Sulawesi Utara. Thesis. Program Pascasarjana. UNSRAT. Manado. $46 \mathrm{Hal}$.

Masengi, K.W.A., 1992. Studies On The Characteristic of A Small Fishing Boat From The Viewpoint Of Seakeeping Quality. Graduate School Of Marine Sience and Engineering. Nagasaki University.

Muckle, W. 1978. Naval Architercture of Marine Engineers. New Butterword and co. $407 \mathrm{P}$

Nomura, M and T. Yamazaki. 1977. Fishing Techniques I. JICA. Tokyo. 206 P.

Santoso, I. G.M. dan J.JH Suyono. 1983. Teori Bangunan Kapal. Direktorat Pendidikan menengah Kejuruan. Depdikbud. Jakarta.

Suryabrata, J. 1987. Metode Penelitian. CV. Rajawali. Jakarta. 126 Hal.

Undang-undang Republik Indonesia No. 21 Tahun 1992. Tentang Pelayaran. Bab I. Ketentuan Umum Pasal 1 Ayat 2. 